\title{
The Relationship Between Innovation Skill and Entrepreneurship on Bachelor Students of Sports Education
}

\author{
Alpaslan Baki Ertekin (Corresponding author) \\ Department of Sports Management, Istanbul Gelişim University \\ Cihangir Mahallesi Şehit Jandarma Komando Er Hakan Öner Sk. No:1 Avcılar, İstanbul, Turkey \\ Tel: 0-212-422-7000Ｅ-mail: abe.akademik@gmail.com
}

\author{
Received: March 13, 2021 Accepted: May 5, 2021 Published: May 14, 2021 \\ doi:10.5296/jei.v7i1.18405 URL: https://doi.org/10.5296/jei.v7i1.18405
}

\begin{abstract}
It is a fact that the concept of innovation, which is a necessity in every field today, is now indispensable in the sports sector. Especially, it is thought that determining the relationship between the innovation skills of the students in sports education institutions and the entrepreneurship of the students who are candidates to work in the sports sector is important in the development of innovation awareness of the students who will work in this field in the future. The aim of this study is to examine the relationship between innovation and entrepreneurship skills of individuals who receive sports education according to different variables. The study group was formed by the voluntary participation of 240 people, 161 males (67.1\%) 79 females (32.9\%), studying at the School of Physical Education and Sports at Istanbul Gelişim University, and selected by the purposeful sampling method. In addition to the personal information form, the Individual Innovativeness Scale (IIS) developed by Hurt et al. (1977) and adapted into Turkish by Sarığlu (2014), and the Entrepreneurship Scale (ES) developed by Y1lmaz and Sünbül (2009) to measure the entrepreneurship levels of university students were used as data collection tools. After the data showed normal distribution, T-Test, ANOVA and Pearson Correlation Test were used in the analyses, and the Tukey test was used to determine the difference between the groups. According to the results, it was determined that the innovation skills and entrepreneurship levels of the individuals' varied according to different variables. As a result, it was determined that as the innovation skills of students studying at institutions providing sports education increased, their level of entrepreneurship also increased.
\end{abstract}

Keywords: Innovation, Innovation skill, Entrepreneurship 


\section{Introduction}

Countries, firms, or businesses that set growth as a target in recent years attach importance to innovation to reveal their differences and create a competitive environment (Evcim, 2017). Because in the modern age we live in, it is known that the competition of countries or companies and enterprises against their competitors is not only limited to cost but also is now necessary to establish a competitive advantage in sectoral areas (Bulut, 2020). The concept, which is derived from the word "innovatus" in Latin (Ekmekci Yüce, 2020) and known as "innovation" in English, is used with the words "inovasyon" and "yenilik" in Turkish (Uzyurt, 2008). Joseph Schumpeter (1934), a pioneer in the emergence of the concept of innovation, has defined innovation as the introduction of a new or advanced product or service, the introduction of new products or sales methods, the opening of a new market or the creation of a new industrial structure (Kasalak, 2020). While the concept of innovation, which has many fields and therefore many definitions, can be defined as the renewal process of science and technology in a way that can benefit economically and socially (Dam, 2017), in 2005, Organization for Economic Cooperation and Development (OECD) have expressed innovation as converting a new idea into a product or service that can be marketed, an improved production or distribution method, or a social service method, and at the same time, it is defined as a marketable, new or improved product, method or service that occurred during this transformation process (Tüysüz, 2020).

It is clear that innovation, which is one of the most frequently used terms of all time, does not have enough information about how businesses will do it and under what conditions it will be marketed. Especially in businesses, the importance of innovation emerges to survive and compete with other businesses. The concept of innovation has great importance not only for businesses but also for states and countries (Gümüş, 2014). Because countries are trying to increase the power of their businesses in the global competitive environment or to maintain their position in the market with the innovation policies they implement. At the same time, with its current innovation potential, it aims to provide a better quality of services to its citizens and as a result, providing a better quality of life by increasing the income level of the country (Özenci, 2017).

Entrepreneurship is a creative human activity and can be defined as establishing an organization and activating this organization (Timmons, 2004). While Joseph Schumpeter is considered the economist who successfully linked innovation and entrepreneurship (Lai et al., 2010), Schumpeter (1934) defined entrepreneurship as establishing new combinations in businesses and applying them. Hisrich et al. (2002) also defined entrepreneurship as the process of producing new things with added value by providing enough power and time by undertaking various problems that may arise with it, gaining independence, personal satisfaction, economic gains. One of the most important factors that complement and support entrepreneurship is innovation (Iş1k et al., 2015). Innovation is important for success in all business risks and entrepreneurship (Şahbaz, 2017). In short, innovation and entrepreneurship are elements that complement each other. It is known that innovation is one of the sources of entrepreneurship. It allows the development of innovation in entrepreneurship and understanding its economic value (Elbaz et al., 2013). This great and strong connection 
between entrepreneurship and innovation reveals the necessity of analysing the two phenomena together (Balkiene \& Jagminas, 2010).

Innovation is not only a requirement of businesses in the competitive world to compete with other businesses or an obligation for businesses to survive, but also is a necessity for the citizens of innovation countries to realize a prosperity environment. Because innovation is an extremely important issue for human life and for the facilitation of human life. Researchers have shown in their studies that innovation is a need and necessity for making life easier and for the individual to be satisfied with life. In addition to innovation, it is seen that entrepreneurship is an essential condition for countries to create employment and their citizens to develop economically. The relationship between innovation and entrepreneurship in the literature also reveals the worth and importance of these facts. It is indisputable that innovation, which should be in all areas of life, should be an indispensable phenomenon in the sports sector. It is expected that the entrepreneurial individuals in this sector, which gradually turns into a big industry and creates a wide employment creation area for countries, will consist of students who have graduated from institutions that provide sports education. In this context, it is thought that it is important for individuals who are candidates to the sports sector to measure the innovation skills and entrepreneurship levels of students studying at sports science faculties and physical education and sports colleges of universities and to determine whether there is a relationship between these phenomena for these students. In this context, this study aimed to determine the differences between the innovation skill and entrepreneurship level of the students studying in institutions providing sports education according to the variables of gender, age, department, and academic success perception and to determine the relationship between innovation skill and entrepreneurship.

\section{Method}

\subsection{Research Model}

In studies, the relational screening model, which describes a situation or an event as it is, was used to determine the relationship, effect and degree of the variables that cause these situations (Kaya et al., 2012). In this study, one of the research methods, the relational screening method was used.

\subsection{Research Group}

The study group of this research consisted of a total of 240 people, 161 males $(67.1 \%)$ and 79 females $(32.9 \%)$, who were selected by purposeful sampling method and studying at the School of Physical Education and Sports in Istanbul Gelisim University.

\subsection{Personal Information Form}

The "Personal Information Form", prepared by the researcher, was used to determine the gender, department, age and academic success perception of the participants

\subsection{Individual Innovativeness Scale (IIS)}

Individual Innovativeness Scale (IIS) was developed by Hurt et al. (1977) and adapted into 


\section{Macrothink

Turkish by Sarığlu (2014). The scale decided to consist of 18 items as a result of the final evaluations and consisted of a 5-point Likert type (1-I don't agree at all, 5-I totally agree). To reveal the general innovativeness level of individuals, the general score obtained by adding the scores from the scale items. To determine the reliability of the scale, the Cronbach alpha internal consistency coefficient was calculated and the internal consistency coefficient was calculated as 0.77 . For this research, the coefficient calculated was determined as 0.81 .

\subsection{Entrepreneurship Scale (ES)}

Entrepreneurship Scale (ES) was developed by Y1lmaz and Sünbül (2009) to measure the entrepreneurship of university students. ES had a structure consisting of 36 items, and 5-point Likert type (1-Never, 2-Rarely, 3-Sometimes, 4-Often, 6-Very often) and one dimension. Cronbach Alpha reliability coefficient of the scale was found to be 0.90 as a result of the reliability analysis. In the reliability analysis for this research, the coefficient was found to be 0.79 .

\subsection{Data Analysis}

Statistical analyses performed by using the SPSS 20.0 package program. Percentage (\%) and frequency (f) methods were used as statistical methods in the evaluation of the data in the research.

Kolmogorov-Smirnov normality test was performed to understand whether the data showed normal distribution and it was understood that the data showed normal distribution $(p>0.05)$. After it was understood that the data were suitable for parametric test conditions, T-Test, ANOVA, Pearson Correlation test was used in statistical analysis, and the Tukey test was used to determine the differences between groups.

Individuals' entrepreneurship levels were evaluated by considering the following scores:

- 36-64 very low entrepreneurship;

- 65-92 low entrepreneurship;

- 93-123 medium level entrepreneurship;

- 124-151 high entrepreneurship;

- 152-180 high level of entrepreneurship. 


\section{Results}

Table 1. Demographic characteristics of individuals

\begin{tabular}{|c|c|c|c|}
\hline & & $\mathrm{f}$ & $\%$ \\
\hline \multirow{3}{*}{ Gender } & Male & 161 & 67.1 \\
\hline & Female & 79 & 32.9 \\
\hline & Total & 240 & 100.0 \\
\hline \multirow{4}{*}{ Department } & Sports Management & 91 & 37.9 \\
\hline & Coaching Training & 79 & 32.9 \\
\hline & Recreation & 70 & 29.2 \\
\hline & Total & 240 & 100.0 \\
\hline \multirow{4}{*}{ Age } & $18-21$ & 121 & 50.4 \\
\hline & $22-25$ & 70 & 29.2 \\
\hline & 26 and older & 49 & 20.4 \\
\hline & Total & 240 & 100.0 \\
\hline \multirow{4}{*}{ Academic Success Perception } & Low & 56 & 23.3 \\
\hline & Normal & 129 & 53.8 \\
\hline & High & 55 & 22.9 \\
\hline & Total & 240 & 100.0 \\
\hline
\end{tabular}

Table 1 consisted of the percentage and frequency information of the demographic information of the participants. According to Table 1, it was determined that $67.1 \%$ of the participants were males and $32.9 \%$ were females. It was understood that $37.9 \%$ of the participants studied in the sports management department, $32.9 \%$ were in the coaching education department and $29.2 \%$ were in the recreation department. It was determined that $50.4 \%$ of the participants were in the $18-21$ age group, $29.2 \%$ were in the $22-25$ age group, and $20.4 \%$ were 26 and older. Considering the academic achievement perception levels of the participants, it was determined that $23.3 \%$ were "low", $53.8 \%$ "normal" and $22.9 \%$ "high". 
Table 2. Distribution of scale scores

\begin{tabular}{|l|l|l|l|l|l|l|l|}
\hline \multicolumn{2}{|l|}{ Sub-dimensions } & Item & $\mathrm{n}$ & Mean & Sd. & Skewness & Kurtosis \\
\hline Individual Innovativeness Scale & Innovation Skill & 18 & 240 & 4.07 & .66 & .372 & .471 \\
\hline Entrepreneurship Scale & Entrepreneurship & 36 & 240 & 4.23 & .80 & .512 & .651 \\
\hline
\end{tabular}

In Table 2, the mean scores of the participants obtained from the scale scores were given. According to the analysis results, while the mean score obtained from the individual innovativeness scale was determined as 4.07, the mean score obtained from the entrepreneurship scale was determined to be 4.23 .

Table 3. Independent T-Test results on scale scores according to the gender variable

\begin{tabular}{|l|l|l|l|l|l|}
\hline & Gender & $\mathrm{n}$ & Mean \pm Sd. & $\mathrm{t}$ & $\mathrm{p}$ \\
\hline \multirow{3}{*}{ Innovation Skill } & Male & 161 & $3.17 \pm 0.80$ & \multirow{2}{*}{0.074} & \multirow{2}{*}{.941} \\
\cline { 2 - 5 } & Female & 79 & $3.16 \pm 0.81$ & & \\
\hline \multirow{2}{*}{ Entrepreneurship } & Male & 161 & $4.06 \pm 0.61$ & \multirow{2}{*}{6.890} & $.000^{*}$ \\
\cline { 2 - 4 } & Female & 79 & $3.81 \pm 0.75$ & & \\
\hline
\end{tabular}

Table 3 consisted of the T-Test results regarding the scale scores of the participants according to their gender. In the analysis results, while no statistically significant difference was found between the innovation skills of individuals according to their gender $(p>0.05)$, a significant difference was determined between the entrepreneurship of individuals according to their gender $(\mathrm{p}<0.05)$.

Table 4. ANOVA results regarding the scale scores according to the department variable

\begin{tabular}{|c|c|c|c|c|c|c|}
\hline & Department & $\mathrm{n}$ & Mean \pm Sd. & $\mathrm{F}$ & $\mathrm{p}$ & Difference \\
\hline \multirow{3}{*}{ Innovation Skill } & Sports Management & 91 & $4.21 \pm 0.58$ & \multirow{3}{*}{4.771} & \multirow{3}{*}{$.009 *$} & \multirow{3}{*}{$1-3$} \\
\hline & Coaching Training & 79 & $4.13 \pm 0.57$ & & & \\
\hline & Recreation & 70 & $3.91 \pm 0.76$ & & & \\
\hline \multirow{3}{*}{ Entrepreneurship } & Sports Management & 91 & $3.22 \pm 0.79$ & \multirow{3}{*}{5.222} & \multirow{3}{*}{$.000 *$} & \multirow{3}{*}{$\begin{array}{l}1-3 \\
2-3\end{array}$} \\
\hline & Coaching Training & 79 & $3.15 \pm 0.85$ & & & \\
\hline & Recreation & 70 & $3.09 \pm 0.77$ & & & \\
\hline
\end{tabular}




\section{Macrothink}

Table 4 consisted of ANOVA results regarding the scale scores of the participants according to their departments. In the analysis results, a statistically significant difference was found between the innovation skills of individuals according to their departments $(p<0.05)$. Similarly, a statistically significant difference was found between the entrepreneurship of individuals according to their departments $(\mathrm{p}<0.05)$.

Table 5. ANOVA results regarding scale scores according to the age variable

\begin{tabular}{|c|c|c|c|c|c|c|}
\hline & Age & $\mathrm{n}$ & Mean \pm Sd. & $\mathrm{F}$ & $\mathrm{p}$ & Difference \\
\hline \multirow{3}{*}{ Innovation Skill } & $18-21$ & 121 & $3.90 \pm 0.53$ & \multirow{3}{*}{1.251} & \multirow{3}{*}{.251} & \\
\hline & $22-25$ & 70 & $3.96 \pm 0.66$ & & & \\
\hline & 26 and older & 49 & $3.80 \pm 0.68$ & & & \\
\hline \multirow{3}{*}{ Entrepreneurship } & $18-21$ & 121 & $3.17 \pm 0.83$ & \multirow{3}{*}{7.351} & \multirow{3}{*}{$.000^{*}$} & \multirow{3}{*}{$\begin{array}{l}1-3 \\
2-3\end{array}$} \\
\hline & $22-25$ & 70 & $3.30 \pm 0.74$ & & & \\
\hline & 26 and older & 49 & $3.35 \pm 0.78$ & & & \\
\hline
\end{tabular}

Table 5 consisted of the results of the ANOVA analysis regarding the scale scores of the participants according to their age groups. In the analysis results, no statistically significant difference was found between the innovation skills of individuals according to age groups $(\mathrm{p}>0.05)$. On the other hand, a significant difference was found between the entrepreneurship of individuals according to their age groups $(\mathrm{p}<0.05)$.

Table 6. ANOVA results regarding scale scores according to academic success perceptions

\begin{tabular}{|l|l|l|l|l|l|l|}
\hline & Academic Success Perceptions & $\mathrm{n}$ & Mean \pm Sd. & $\mathrm{F}$ & $\mathrm{p}$ & Difference \\
\hline \multirow{5}{*}{ Innovation Skill } & Low & 56 & $4.00 \pm 0.63$ & & & \\
\cline { 2 - 5 } & Normal & 129 & $4.07 \pm 0.62$ & 5.842 & $.020^{*}$ & $1-3$ \\
\cline { 2 - 5 } & High & 55 & $4.12 \pm 0.77$ & & & \\
\hline \multirow{3}{*}{ Entrepreneurship } & Low & 56 & $3.12 \pm 0.69$ & & & \\
\cline { 2 - 5 } & Normal & 129 & $3.14 \pm 0.71$ & \multirow{2}{*}{1.257} & .286 & \\
\cline { 2 - 4 } & High & 55 & $3.15 \pm 0.72$ & & & \\
\hline
\end{tabular}

Table 6 consisted of the results of ANOVA analysis regarding the scale scores according to the academic achievement perceptions of the participants. In the analysis results, a 
statistically significant difference was found between innovation skills according to the academic achievement perceptions of individuals $(\mathrm{p}<0.05)$. On the other hand, no statistically significant difference was found between the entrepreneurship of individuals according to their perceptions of academic achievement $(p>0.05)$.

Table 7. Results of correlation analysis between innovation skills and entrepreneurship scores

\begin{tabular}{|l|l|l|}
\hline & Innovation Skill & Entrepreneurship \\
\hline Innovation Skill & 1 & $0.328^{*}$ \\
\hline Entrepreneurship & $0.328^{*}$ & 1 \\
\hline
\end{tabular}

Table 7 consisted of the analysis results regarding the relationship between innovation skill and entrepreneurship. In the analysis results, a moderate statistically positive relationship was found between individual innovation and entrepreneurship $(\mathrm{p}<0.05 ; \mathrm{r}=0.32)$.

\section{Discussion}

Nowadays, both countries, businesses, companies, and institutions should have considered and performed innovation. Because the reason to exist in the competitive environment of today's world was an innovation. Innovation has become an indispensable phenomenon in the sports sector, which has turned into a big industry with rapid development especially in recent years. It was known that individuals who graduated from different departments of sports science faculties of universities were the highest candidates to work in the sports sector. Their entrepreneurship was the most important factor for the institutions and businesses they work for and even the growth of the country in the field of sports. Therefore, the importance of entrepreneurship and innovation skills of individuals studying at these faculties have increased more in recent years. Thus, research hypotheses were established, and while it was aimed to determine the innovation skills and entrepreneurship levels of the individuals who continue their education in these faculties, the main aim was to determine the relationship between these two phenomena.

In the results, the mean scores that the individuals obtained in the scale were determined. Considering the mean scores, it was determined that the mean that individuals obtained from their innovation skills was 4.07. At entrepreneurship levels, the mean score obtained was 4.23. According to the mean scores, it can be said that the innovation skills of individuals studying at sports science faculties were at a medium level. In the study conducted by Ertuğ and Kaya (2017) on students studying at the nursing faculty, it was found that individuals studying at this faculty had low innovation skills. In the study conducted by Atalay (2018), it was determined that the individuals working in the Youth Services and Sports Provincial Directorate had a medium level of innovation. Considering the entrepreneurship levels, it can be said that the entrepreneurship levels of individuals studying at sports science faculties were at a high level. In studies conducted by (Özmen, 2015; Mülhim, 2019; Koh, 1996; Kaya 
et al., 2011), it was determined that individuals studying at university had high levels of entrepreneurship.

In the results, no statistically significant difference was found between the innovation skills of individuals according to their gender. In the studies conducted by Akça and Şakar (2018), Kosa (2019), Yeğin (2017), no differentiation in innovation skill was determined between genders. The results of this research and the results of the studies were in parallel. A statistically significant difference was found between the entrepreneurship levels of individuals according to their gender. The mean scores of male individuals were determined to be higher than female individuals, and it can be said that the entrepreneurship level of male was higher than female. It was seen that this situation was not parallel with some studies in the literature (Adatepe, 2018; Karataş, 2018; Özman, 2013). It could be said that this situation may differ from university to university, and from faculty to faculty.

According to the results, a statistically significant difference was found between the innovation skills of the individuals according to the departments they studied. It was determined that the significant difference was in favour of the students studying in the "sports management" department. It could be said that the innovation skills of the individuals studying in this department were higher than the individuals who study in the "Coaching Training" and "Recreation" departments. Particularly, the fact that the individuals studying in the department of sports management were in a more theoretical field, the course contents were educated in multi-disciplinary fields such as marketing, law, and accounting can be thought to be the reason for the higher innovation skills of the students in this department. It was determined that there was a statistically significant difference in the entrepreneurship levels of the individuals according to their departments. Considering the innovation skills, it was determined that the individuals studying in the "sports management" department had higher levels of entrepreneurship than the individuals studying in the "coaching training" and "recreation" departments. Significant differences were also determined between individuals studying in the "coaching training" department and those studying in the "recreation" department.

In the research results, no statistically significant difference was found between the innovation skills of individuals according to age groups. In the study conducted by Keleş et al. (2020) on individuals studying at the tourism faculty, no significant difference was found between individuals' perceptions of innovation by age groups. However, in this study and the study conducted by Keleş et al. (2020), it was observed that innovation skills increased with age. Although the difference between the mean was not statistically significant, it can be said that innovation skills increased with age. A statistically significant difference was found between the entrepreneurship levels of individuals according to their age groups. It was determined that the significant difference was in favour of individuals aged 26 and over.

According to the results of the research, a statistically significant difference was found between innovation skills according to the academic achievement perception levels of the individuals. Considering the difference between the groups, it was seen that the academic success perception level was between "high" and "low", and it could be said that individuals 
with a "high" academic success perception had higher innovation skills. This was the expected result. It can be expected that the innovation skills of successful people in the training process were high. In the results of the research, no significant difference was found between the entrepreneurship levels according to the innovation success perception of the individuals.

The main aim of the research was to determine the relationship between innovation skills and entrepreneurship. Numerous studies were conducted in various fields to identify this relationship in the literature (Işı et al., 2015; Braunerhjelm, 2010; Brem, 2008; İrmiş \& Özdemir, 2011; Hine, \& Kapeleris, 2006; Link \& Siegel, 2007; Şahbaz, 2017). However, it was observed that researching the relationship between innovation and entrepreneurship, which was especially in great need of the sports industry, on students studying at the sports science faculties of universities, who were candidates to work in every field of the sports industry, was found to be limited. As a result of the research, a moderate positive correlation was found between innovation skill and entrepreneurship according to the scale scores obtained from students studying at the sports science faculty. This showed that the more innovation skills of students studying at the sports science faculty increased, the more their entrepreneurship increased. Therefore, it can be thought that studies should be performed to increase the innovation skills of individuals who will work in the sports sector during their education, and that course content should be created to raise awareness of these students about innovation.

\section{References}

Adatepe, S. (2018). Beden Eğitimi ve Spor Yüksekokulu'nda Okuyan Öğretmen Adaylarının Girişimcilik Özellikleri İle Yansıtıcı Düşünme Düzeylerinin İncelenmesi (Yüksek Lisans Tezi, Bartın Üniversitesi/Eğitim Bilimleri Enstitüsü, Bartın).

Akça, F., \& Çakar, Z. (2018). Öğretmen Adaylarının Bireysel Yenilikçilik Düzeylerinin Incelenmesi. In Ö. Demirel, \& S. Dinçer (Eds.), Küreselleşen Dünyada Eğitim. https://doi.org/10.14527/9786053188407.29

Atalay, A. (2018). Gençlik Hizmetleri ve Spor İl Müdürlüğü Çalışanlarının Bireysel Yenilikçilik Düzeyi. Turkish Studies, 13(10), 87-107. https://doi.org/10.7827/TurkishStudies. 13121

Balkiene, K., \& Jagminas, J. (2010). Allusion To Public Policy: Innovative Entrepreneurship. Public Policy and Administration, 34, 32-46.

Braunerhjelm, P. (2010). Entrepreneurship, Innovation and Economic Growth-Past Experiences, Current Knowledge and Policy Implications (No. 2010:2). Working Papers, Swedish Entrepreneurship Forum.

Brem, A. (2008). The Boundaries of Innovation and EntrepreneurshipConceptual Background and Essays on Selected Theoretical and Empirical Aspects. Wiesbaden: Betriebswirtschaftlicher Verlag.

Bulut, T. (2020). Malatya Makine Imalat Sanayinde Ar-Ge ve Inovasyon Düzeyinin 
Araştırılması (Yüksek Lisans Tezi, İnönü Üniversitesi Fen Bilimleri Enstitüsü Makine Mühendisliği Anabilim Dalı, Malatya).

Dam, M. (2017). Ar-Ge, Inovasyon Ve Ekonomik Büyüme. Ekin Kitabevi Yayınları, Bursa.

Ekmekci Yüce, M. (2020). Döngüsel Ekonomi ve Yeşil Yönetim Uygulamalarının Inovasyon Üzerinden Firmanın Büyüme Performansı Üzerine Etkisi (Doktora Tezi, Beykent Üniversitesi Lisansüstü Eğitim Enstitüsü İşletme Anabilim Dalı İşletme Yönetimi Bilim Dalı, İstanbul).

Elbaz, J., Binkour, M., \& Majdouline, I. (2013). Innovation and entrepreneurship: An empirical study of Moroccan firms (pp. 1-23).

Ertuğ, N., \& Kaya, H. (2017). Hemşirelik Öğrencilerinin Bireysel Yenilikçilik Profilleri ve Yenilikçiliğin Önündeki Engellerin İncelenmesi. Hemşirelikte Eğitim ve Araştırma Dergisi, 14(3), 192-197.

Evcim, N. (2017). Ar-Ge ve Inovasyona Faaliyetleri ile Büyüme Ilişkisi (Yüksek Lisans Tezi, Pamukkale Üniversitesi Sosyal Bilimler Enstitüsü Yüksek Lisans Tezi İktisat Ana Bilim Dalı İktisat Programı, Denizli).

Gümüş, S. (2014). İnovasyonu Oluşturan İşletmelerin Yaşam Döngüleri. Baskı, Eğitim İletişim Yayınları, İstanbul.

Hine, D., \& Kapeleris, J. (2006). Innovation and Entrepreneurship in Biotechnology, an International Perspective: Concepts, Theories and Cases. Cheltenham: Edward Elgar Publishing. https://doi.org/10.4337/9781845428853

Hisrich, R. D., \& Peters, M. P. (2002). Entrepreneurship (6th ed.). New York, McGrawHill Education.

Hurt, H. Y., Joseph, K., \& Cook, C. D. (1977). Scales for the measurement of innovativeness. Human Communication Research, 4, 58-65. https://doi.org/10.1111/j.1468-2958.1977. tb00597.x

İrmiş, A., \& Özdemir, L. (2011). Girişimcilik ve Yenilik İlişkisi. Yönetim Bilimleri Dergisi, 9(1), 135-162.

Işık, N., Işık, H. B., \& Kılınç, E. C. (2015). Girişimcilik ve İnovasyon İlişkisi: Teorik Bir Değerlendirme. JEBPIR, 1(2), 57-90.

Karataş, İ. (2018). Beden Eğitimi ve Spor Yüksekokulu Öğrencilerinin Kişilik Özelliklerinin Girişimcilik Eğilimleri Üzerindeki Etkilerinin Incelenmesi: Bartın Üniversitesi Örneği (Yüksek Lisans Tezi, Bartın Üniversitesi Eğitim Bilimleri Enstitüsü Beden Eğitimi Ve Spor Öğretimi Ana Bilim Dalı Beden Eğitimi ve Spor Eğitimi Bilim Dalı, Bartın).

Kasalak, S. (2020). Açık Inovasyon ile Örgüt Kültürü ve Sosyal Ağlar Ilişkisi: Türkiye’de Bilişim Sektöründe Bir Araştırma (Doktora Tezi, Ankara Üniversitesi Sosyal Bilimler Enstitüsü İşletme Anabilim Dal1, Ankara). https://doi.org/10.33537/sobild.2020.11.2.17

Kaya, A., Balay, R., \& Göçen, A. (2012). Öğretmenlerin Alternatif Ölçme ve Değerlendirme 
Tekniklerine Ilişkin Bilme, Uygulama ve Eğitim Ihtiyacı Düzeyleri. International Journal of Human Sciences, 9(2), 1303-5134.

Kaya, D., Güzel, D., \& Çubukçu, B. (2011). Üniversite Öğrencilerinin Girişimcilik Eğilimlerinin Araştırılması: Atatürk Üniversitesinde Bir Araştırma. Kafkas Üniversitesi I.I.B.F. Dergisi, 2(1), 76-89.

Keleş, H., Çınar, K., \& Akmeşe, H. (2020). Turizm Fakültesi Öğrencilerinin Bireysel Inovasyon Algılarının Bölüm Memnuniyetine Etkisi. Journal of Humanities and Tourism Research, 10(3), 664-679. https://doi.org/10.14230/johut888

Koh, H. C. (1996). Testing hypotheses of entrepreneurial characteristics a study of Hong Kong MBA students. Journal of Managerial Psychology, 3, 12-25. https://doi.org/10.1108/ 02683949610113566

Kosa, G. (2019). Yöneticilerinin Girişimcilik ve İnovasyon Algılarının İncelenmesi: Kobi Yöneticileri Üzerine Bir Araştırma, İşletme Araştırmaları Dergisi, 11(3), 1792-1806. https://doi.org/10.20491/isarder.2019.706

Lai, K. P., Nathan, R. J., Tan, K. S., \& Chan, B. B. (2010). Effect of Innovation to the Success of Female Entrepreneurs. Journal of Innovation Management in Small and Medium Enterprises, 2010, Article ID 369877. https://doi.org/10.5171/2010.369877

Link, A. N., \& Siegel, D. S. (2007). Innovation, Entrepreneurship and Technological Change. New York: Oxford University Press Inc. https://doi.org/10.1093/acprof:oso/9780199268825. 001.0001

Mülhim, Z. (2019). Beden Eğitimi ve Spor Yüksekokulu Öğrencilerinin Girişimcilik Özellikleri ve Bireysel Yenilikçilik Düzeylerinin Incelenmesi: Bartın üniversitesi örneği (Yüksek Lisans Tezi, Bartın Üniversitesi Eğitim Bilimleri Enstitüsü Beden Eğitimi ve Spor Öğretimi Ana Bilim Dalı Beden Eğitimi Ve Spor Eğitimi Bilim Dalı. Bartın).

Özenci, C. (2017). Yönetim, Liderlik ve Değişim Bağlamında, Gençlik Merkezi Yöneticilerinin Inovasyon Yeterliliklerinin Ölçülmesi; Bir Alan Araştırması (Yüksek Lisans Tezi, Hitit Üniversitesi Sosyal Bilimler Enstitüsü Beden Eğitimi Ve Spor Ana Bilim Dalı, Çorum).

Özman, C. (2013). Spor Yöneticiliği Bölümünde Öğrenim Gören Üniversite Öğrencilerinin Girişimcilik Düzeyinin Değerlendirilmesi (Yüksek Lisans Tezi. Marmara Üniversitesi Sağlık Bilimleri Enstitüsü Beden Eğitimi Ve Spor Anabilim Dalı, İstanbul).

Özmen, Ç. (2015). Rekreasyon ve Spor Yöneticiliği Bölümü Öğrencilerinin Girişimcilik Düzeylerinin Değerlendirilmesine Yönelik Bir Çalışma (Yüksek Lisans Tezi, Mehmet Akif Ersoy Üniversitesi Eğitim Bilimleri Enstitüsü Beden Eğitimi ve Spor Öğretmenliği Anabilim Dalı, Burdur).

Şahbaz, A. (2017). İnovasyon ve Girişimcilik Kavramlarının Karşılıklı Etkileşimi. Girişimcilik İnovasyon ve Pazarlama Araştırmaları Dergisi, 1(1), 20-38. https://doi.org/ 10.31006/gipad.322084 


\section{Macrothink}

Journal of Educational Issues

ISSN 2377-2263

2021, Vol. 7, No. 1

Sarıŏlu, A. (2014). Bireysel Yenilikçilik Ölçeğinin Hemşirelikte Geçerlik ve Güvenirliği (Yayınlanmamış Yüksek Lisans Tezi, Atatürk Üniversitesi Sağlık Bilimleri Enstitüsü Hemşirelikte Yönetim Anabilim Dalı, Erzurum).

Schumpeter, J. (1934). Theory of Economic Development. Cambridge, Harvard University Press.

Timmons, J. A. (2004). New Venture Creation, Entrepreneurship in the 1990s. McGraw Hill, Boston.

Tüysüz, H. (2020). Araştırma-Geliştirme ve Inovasyon Çalışmalarında Devletin Rolü: Kosgeb Örneği (Doktora Tezi, Zonguldak Bülent Ecevit Üniversitesi Sosyal Bilimler Enstitüsü İktisat Anabilim Dalı, Zonguldak).

Uzyurt, C. (2008). Pazarlamada Değer Yaratma Aracı Olarak Yenilik Yönetimi ve Yenilikçi Örgüt Kültürü. İstanbul, Beta Basım Yayın.

Yeğin, H. İ. (2017). İlahiyat fakültesi öğrencilerinin bireysel yenilikçilik düzeyleri. $A \dot{I} B \ddot{U}$ Sosyal Bilimleri Enstitüsü Dergisi, 17(4), 239-262. https://doi.org/10.11616/basbed.vi.459398

Y1lmaz, E., \& Sünbül, A. M. (2009). Üniversite Öğrencilerine Yönelik Girişimcilik Ölçeğinin Geliştirilmesi. Selçuk Üniversitesi Sosyal Bilimler Enstitüsü Dergisi, 21, 195-203.

\section{Copyright Disclaimer}

Copyright for this article is retained by the author(s), with first publication rights granted to the journal.

This is an open-access article distributed under the terms and conditions of the Creative Commons Attribution license (http://creativecommons.org/licenses/by/3.0/). 